\title{
Clinical pharmacology profile of care in Hepatology clinic
}

\author{
Talita Rocha Passos ${ }^{1 *}$, Fabiana Silla Santos ${ }^{1}$, Maria Cleusa Martins ${ }^{2}$, Vanusa Barbosa Pinto ${ }^{3}$, Flair José Carrilho ${ }^{4}$, \\ SUZANE KIOKO ONO ${ }^{5}$ \\ ${ }^{1}$ Resident Pharmacist at Faculdade de Medicina da Universidade de São Paulo (FMUSP), São Paulo, SP, Brazil \\ ${ }^{2}$ Head Pharmacist, Instituto Central, Hospital das Clínicas da Faculdade de Medicina da Universidade de São Paulo (HC-FMUSP), São Paulo, SP, Brazil \\ 3Pharmacy Director, Instituto Central at HC-FMUSP and the Pharmaceutical Assistance Division at HC-FMUSP, São Paulo, SP, Brazil \\ ${ }^{4}$ Full Professor of Medical Gastroenterology, Head of the Gastroenterology Department, FMUSP, São Paulo, SP, Brazil \\ ¿Associate Professor, Gastroenterology Department, FMUSP, São Paulo, SP, Brazil
}

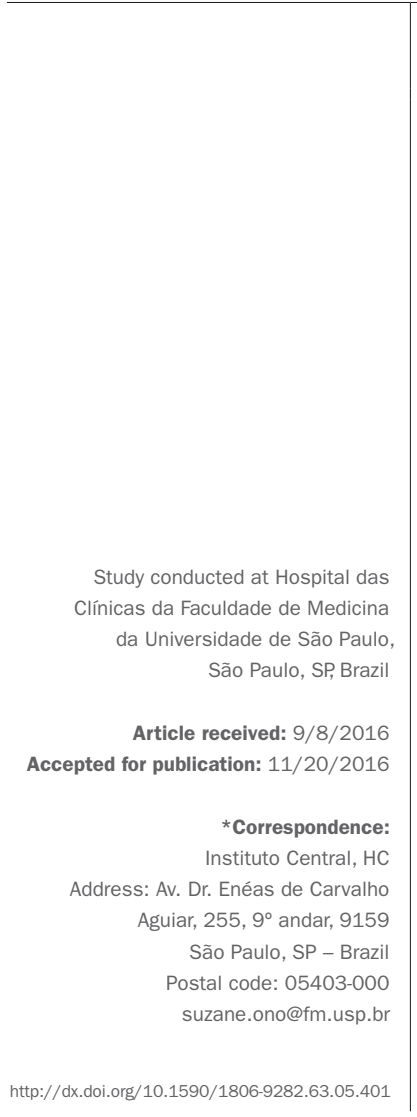

\section{INTRODUCTION}

The system of referral and counter-referral of the Unified Health System (SUS, in the Portuguese acronym) is the two-way referral of patients between the different levels of complexity of the services. The first means the referral of patients from a service of lower complexity to a service of greater complexity, assisting the patient and scheduling their procedure. Counter-referral, in turn, is when the patient can be sent back to their service of origin for treatment maintenance and follow-up. ${ }^{1}$

The referral and counter-referral network is developed on the basis of four components that function in an integrated manner. Primary Health Care (PHC) services are the patient's place of entry for the entire network; secondary care is made up of specialized outpatient clinics and hospitals of medium complexity; the tertiary network aggregates high-complexity hospitals. All are supported by logistics systems, regulation, health transport and electronic health records, as well as support systems, pharmaceutical assistance, diagnostic and therapeutic support. ${ }^{2}$

The Hospital das Clínicas of the University of São Paulo Medical School (HC-FMUSP, in the Portuguese acronym) has a Liver Care project that functions in line with the SUS referral and counter-referral system, in the NGA-63 Várzea do Carmo Outpatient Specialty Clinic, Health Assistance Management Center, in São Paulo.

This service unit has three pharmacies: one outpatient, one for specialized components and one for oncologic medication focused on the care of patients being treated for breast and prostate cancer. 
The Hepatology sector in Várzea do Carmo has a database created from a questionnaire that records the drugs used by patients and the place where they collect their prescriptions. In this database, in addition to patient demographics, there is also information about diagnosis, medical specialties, use of medicines, facilities dispensing these patients' prescriptions, the possibility of acquiring them in the event they are not available for free, and data revealing their knowledge about the drugs they use.

The main services performed at Várzea do Carmo Medical Hepatology Outpatient Clinic are for viral hepatitis and hepatic steatosis. Therefore, it is important, in order to guarantee adequate assistance to the patient, to understand their profile in light of the concepts of polypharmacy. Polymedication, according to Bjerrum et al., is also known as minor polymedication, when the patient uses two to four drugs, and major polymedication, which is when there are five or more drugs of daily and continuous use. ${ }^{3}$

Our study, based on the database mentioned above, uses this concept to address the profile of patients seen at the Várzea do Carmo Hepatology Outpatient Clinic.

\section{Objective}

To analyze the pharmacotherapeutic profile of patients attended by the Clinical Hepatology sector in the Outpatient Specialty Clinic, Secondary Level, Várzea do Carmo, according to the definition of polypharmacy.

\section{Method}

Cross-sectional study, with retrospective data collection, from March to July 2015, in the Hepatology sector of the Outpatient Specialty Clinic, Secondary Level, São Paulo, State of São Paulo.

The study population included patients who were enrolled in the Hepatology database, aged 18 years or older. Patients whose data were non-existent or incomplete were excluded from the database. The research project was approved by the Research Ethics Committee of HCFMUSP (CAPPesq) with CAAE: 53491816.1.0000.0068 Opinion number 1.433.847 on March 2, 2016.

Information on demographics, diagnosis, specialties in which the patient is treated, medications, dosage, information on the patient's knowledge of the use of their medications, the facility dispensing the drugs and the possibility of each patient to acquire the medication in case that particular drug is not available in the network's pharmacies were transported to the REDCAP, a tool for Data Management in Scientific Research. The results were submitted to descriptive statistical analysis and expressed in tables and charts.

\section{Results}

Based on the database of the Hepatology and Gastroenterology Department of the Várzea do Carmo Outpatient Specialty Clinic, from March to July 2015, 492 patients were identified after visiting the Hepatology sector, totaling 1,931 consultations in the period. Of the patients treated, 304 (61.79\%) were female and 188 (38.21\%) were male. The mean age of the general population was 58.87 years, with a standard deviation of \pm 13 years. As for place of residence, 368 (74.80\%) patients resided in the city of São Paulo, while 124 (25.20\%) resided in the greater São Paulo area.

The main liver diagnoses are shown in Table 1.

\begin{tabular}{|c|c|c|c|}
\hline $\begin{array}{l}\text { Main liver } \\
\text { diagnosis }\end{array}$ & $\begin{array}{l}\text { Number } \\
\text { of patients }\end{array}$ & $\begin{array}{l}\text { Female } \\
\text { n (\%) }\end{array}$ & $\begin{array}{l}\text { Male } \\
\text { n (\%) }\end{array}$ \\
\hline Hepatitis C & 172 & $89(51.75 \%)$ & $83(48.25 \%)$ \\
\hline Hepatic steatosis & 112 & $77(68.75 \%)$ & $35(31.25 \%)$ \\
\hline Cirrhosis & 72 & 30 (41.67\%) & $42(58.33 \%)$ \\
\hline Hepatitis B & 35 & $19(54.28 \%)$ & $16(45.72 \%)$ \\
\hline Under investigation & 62 & $40(64.51 \%)$ & $22(35.49 \%)$ \\
\hline Other diagnoses & 78 & $42(57.85 \%)$ & $36(46.15 \%)$ \\
\hline Total & $531^{*}$ & & \\
\hline
\end{tabular}

These patients are also assisted by other specialties in the Várzea do Carmo outpatient clinic, at the Clinics Hospital of São Paulo, and in other primary, secondary or tertiary care centers. The most prevalent clinics were those of internal medicine 110 (22.35\%), cardiology 98 (19.92\%), endocrinology 79 (16.06\%), gastroenterology 68 (13.82\%), and rheumatology 62 (12.60 \%) and ophthalmology 44 (8.94\%).

As for the facilities where the patients collected their medications, we noted that: 317 (74.59\%) would get them from Primary Health Units (UBS, in the Portuguese acronym), 110 (25.88\%) from the Várzea do Carmo Outpatient Specialty Clinic and 36 (8.47\%) from HC-FMUSP.

According to the information contained in the database, 373 (87.76\%) patients correctly reported the name, quantity and purpose of all medications used daily, while $52(12.24 \%)$ did not know how to give any of the requested information.

Regarding the possibility of acquiring the drug, 258 (60.8\%) patients reported having the possibility of buying the medication if the drug was not available for free or when it was a drug that is not listed in the governmentfunded medication program on a federal, state or municipal level. Another 54 (12.5\%) could buy it, depending 
on the price of the medication, but 113 (26.7\%) reported not being able to purchase the prescribed medication, regardless of the price.

Table 2 demonstrates that omeprazole, metformin, losartan, hydrochlorothiazide, simvastatin and enalapril were the medications most frequently cited by patients in a list of 33 spontaneous citations.

Of the drugs spontaneously reported by patients, treatment for hepatitis B was cited by 12 patients and treatment for hepatitis $\mathrm{C}$ by two.

\section{TABLE 2 Distribution of patients according to their} medication $(n=425)$

\begin{tabular}{|c|c|c|}
\hline Medications & Total & Percentage (\%) \\
\hline Omeprazole & 208 & 42.28 \\
\hline Metformin & 132 & 26.83 \\
\hline Losartan & 80 & 16.26 \\
\hline Hydrochlorothiazide & 77 & 15.65 \\
\hline Simvastatin & 67 & 13.62 \\
\hline Enalapril & 62 & 12.60 \\
\hline Propranolol & 60 & 12.20 \\
\hline Levothyroxine & 53 & 10.77 \\
\hline Amlodipine & 50 & 10.16 \\
\hline Atenolol & 50 & 10.16 \\
\hline Acetylsalicylic acid & 40 & 8.13 \\
\hline Insulin & 35 & 7.11 \\
\hline Spironolactone & 32 & 6.50 \\
\hline Captopril & 26 & 5.28 \\
\hline Furosemide & 25 & 5.08 \\
\hline Dipyrone & 24 & 4.88 \\
\hline Glicazide & 24 & 4.88 \\
\hline Calcium & 23 & 4.67 \\
\hline Vitamin D3 & 23 & 4.67 \\
\hline Alendronate & 18 & 3.66 \\
\hline Paracetamol & 17 & 3.46 \\
\hline Glibenclamide & 14 & 2.85 \\
\hline Domperidone & 13 & 2.64 \\
\hline Pantoprazole & 11 & 2.24 \\
\hline Prednisone & 11 & 2.24 \\
\hline Bromopride & 10 & 2.03 \\
\hline Fluoxetine & 9 & 1.83 \\
\hline Lactulose & 9 & 1.83 \\
\hline Tenofovir & 7 & 1.42 \\
\hline Entecavir & 4 & 0.81 \\
\hline Interferon & 2 & 0.41 \\
\hline Ribavirin & 2 & 0.41 \\
\hline Adefovir & 1 & 0.20 \\
\hline Other & 219 & 44.51 \\
\hline
\end{tabular}

As for use of medication, we found that 425 (86.38\%) patients used some medication, while only 67 (13.62\%) did not use any. Therefore, 425 patients will be investigated for polypharmacy. Table 3 and Chart 1 show the patient's classification according to Bjerrum et al. ${ }^{3}$

TABLE 3 The pharmacotherapeutic profile according to the classification by Bjerrum et al. with the five drugs most often prescribed to patients on minor polymedication and the ten most often prescribed to patients on major polymedication.

\begin{tabular}{|c|c|c|}
\hline Drug & $\begin{array}{l}\text { Minor } \\
\text { polymedication } \\
n=425\end{array}$ & $\begin{array}{l}\text { Major } \\
\text { polymedication } \\
n=425\end{array}$ \\
\hline Omeprazole & $154(36.23 \%)$ & $86(20.23 \%)$ \\
\hline Metformin & $72(16.94 \%)$ & $62(14.58 \%)$ \\
\hline Losartan & $43(10.11 \%)$ & $44(10.35 \%)$ \\
\hline Hydrochlorothiazide & $43(10.11 \%)$ & $34(8.00 \%)$ \\
\hline Enalapril & $38(8.94 \%)$ & $34(8.00 \%)$ \\
\hline Amlodipine & - & $33(7.76 \%)$ \\
\hline Simvastatin & - & $33(7.76 \%)$ \\
\hline Acetylsalicylic acid & - & $32(7.52 \%)$ \\
\hline Propranolol & - & $25(5.88 \%)$ \\
\hline Levothyroxine & - & $24(5.64 \%)$ \\
\hline
\end{tabular}

\section{Discussion}

The sex and age distribution found in our study is in line with what we expected. Likewise, the distribution of diagnoses among the population served is in accordance with the distribution of these conditions in the general population.

The study demonstrates that a patient can be treated simultaneously at the primary, secondary and even tertiary level of care. The factor keeping a particular patient in tertiary care is the medicines he or she uses, that is, if they are not available in primary or secondary care.

Within this scope, where it is observed that these patients will continue to require specialized or ultra-specialized services, i.e. tertiary care, we are able to say that the concern for rational use of medicines is of note. ${ }^{2}$

Our patients collect their medication from different facilities such as Primary Care Units, the Várzea do Carmo Outpatient Specialty Clinic and the FMUSP Hospital das Clínicas. For the same reasons cited above, dispensing centers are also classified according to complexity and not all medicines are available from the same location.

From a viewpoint of the safe and rational use of medication, there is control over the use of medical prescriptions, because each dispensing facility indicates in 


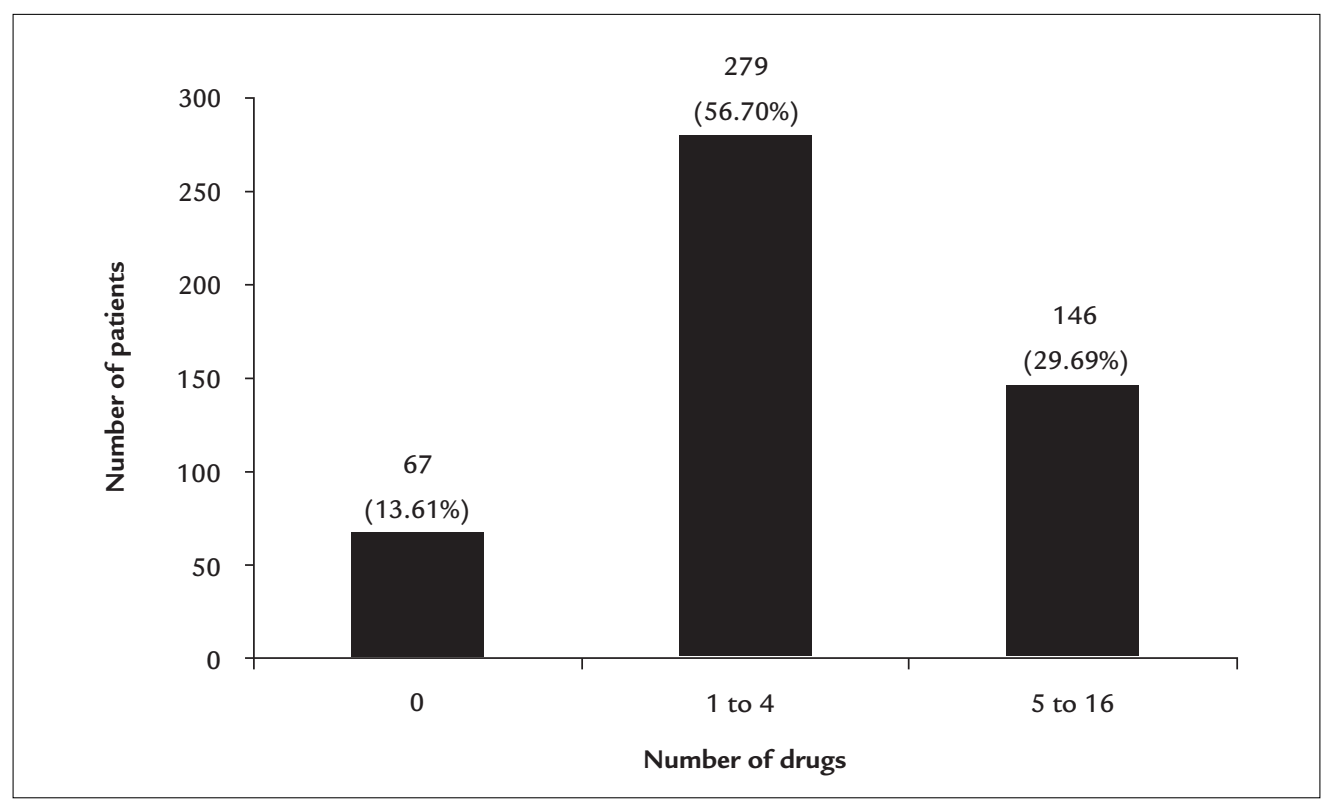

CHART 1 Number of patients vs. number of drugs ( $\mathrm{n}=492)$.

the prescription that the drug was delivered. However, a patient who consults with more than one prescribing physician can have the same prescription repeated and, with different prescriptions, receive more medication than needed.

Comparing the above data with the information obtained in the database about the patients' lack of knowledge about their medications, misuse is a possibility. In addition, too much medication in a patient's possession can lead to self-medication, either through overuse or sharing.

Considering also that some patients mentioned the impossibility of acquiring prescription items if these drugs were not available for free, care about rational use is even more justified as a measure to avoid shortage and waste that can burden the public service.

Omeprazole is one of the drugs most frequently mentioned by patients, which, outside the scope of gastroenterology, raises the question of whether the drug is being used rationally. Omeprazole may alter the metabolism of other drugs by enhancing or reducing their effects, exposing patients to unnecessary side effects and drug interactions without proper monitoring. ${ }^{4-6}$

Regarding the findings of medication use, the 67 patients who do not use any medication are those that are still under investigation, through laboratory tests. There were still no medical prescriptions for these patients at the time of the study and therefore they were excluded from the analysis.

Comparing the drugs most often mentioned with the diseases for which they are indicated, we found:
- Type 2 diabetes mellitus: biguanine (metformin).

- High blood pressure: diuretics (hydrochlorothiazide), angiotensin converting enzyme inhibitor (enalapril), angiotensin receptor antagonists (losartan).

- Dyslipidemia: hydroxymethylglutaryl-coenzyme A (HMG-CoA) reductase inhibitor (simvastatin).

Diabetes is growing worldwide; it is estimated that 382 million people have the disease and that it should reach 471 million people by $2035 .{ }^{4}$ Systemic hypertension showed prevalence $>30 \%$ in Brazilian cities in recent years, which means blood pressure (BP) levels $\geq 140 / 90 \mathrm{mmHg}^{7}$

Dyslipidemia, a growing disease in Brazil and the world, is one of the risk factors for overweight, along with diabetes. Without medical follow-up, dyslipidemia and obesity may directly affect hepatic steatosis, the second most frequently cited diagnosis. Steatosis can progress to hepatitis and cirrhosis. ${ }^{8-17}$

Comparing the mean age of patients (58 years) and their comorbidities (compatible with the age of these patients and the need for chronic medication use), we found justification for the observation of polypharmacy in all patients.

Based on the classification by Bjerrum et al., we were able to correlate medications and diagnoses. Among the cases of minor polymedication, we found diabetes mellitus and systemic hypertension, while major polymedication was also found in cases of diabetes mellitus and hypertension but with additional drug treatment, which indicates 
worsening of the disease. ${ }^{3}$ In some cases, there is also the possibility of complications caused by liver disease, such as portal hypertension with the use of propranolol and problems related to hepatitis $\mathrm{C}$ and its treatment, including hypothyroidism, which requires levothyroxine. ${ }^{18}$

The observation that only 12 of the 35 patients with hepatitis B virus cite medications for the treatment of this disease is suggestive that inactive diseases may be present in the remaining patients.

A patient with an inactive disease requires specific tests such as normal alanine aminotransferase (ALT) and serum HBV DNA levels below $2,000 \mathrm{IU} / \mathrm{mL}$. The serological profile observed is HBeAg-negative in patients with chronic inactive hepatitis. To confirm the diagnosis of inactive disease over time, it is necessary to perform periodic examinations such as ALT, on a quarterly basis, and measurements of HBV DNA and serum HBsAg levels every 12 months to confirm viral elimination. Given these criteria, pharmacological treatment is not recommended, but medical followup of these patients is of paramount importance, ${ }^{19,20}$ maintaining them in the secondary care system.

Only two patients out of 172 cited pharmacological treatment for hepatitis $\mathrm{C}$, which may be due to the riskbenefit assessment of drugs available at the time, given their adverse reactions, such as anemia, thrombocytopenia, rash, neutropenia and more. The therapeutic arsenal for the treatment of chronic hepatitis C (ICD-10: 18.2) in the study period was: alpha-interferon $2 \mathrm{~b}$, alpha- 2 interferon $2 \mathrm{a}$ and $2 \mathrm{~b}$, ribavirin, epoetin alpha, filgrastim, telaprevir and boceprevir, according to the Clinical Protocol and Therapeutic Guidelines for Chronic Viral Hepatitis $\mathrm{C}$ and Coinfections, published in 2013. ${ }^{21}$

With the proposed inclusion of new drugs (sofosbuvir, daclatasvir and semiprevir), which have proven efficacy and minimal adverse reactions, we chose in most cases to await the release of the new drugs. These drugs are currently part of the Clinical Protocol and Therapeutic Guidelines for Chronic Viral Hepatitis C and Coinfections published in 2015, and patients who meet the criteria of this protocol may already benefit from treatment. ${ }^{22,23}$

\section{Conclusion}

The results demonstrated that the study population is adult or elderly, with several comorbidities and, therefore, users of polymedication. The fact that patients in general have access to several prescribing physicians and thus the possibility of duplicity of prescriptions is important to ensure rational use of the drug in a multiprofessional team.

The patients treated have diagnoses that are consistent with the Hepatology sector, demonstrating that the refer- ral and counter-referral system can remove this patient from the tertiary health system, but this does not make his or her care less complex, since the patient remains allocated in the three levels of attention.

\section{Resumo}

Perfil clínico farmacológico dos atendimentos no ambulatório de Hepatologia

Desde 2010, a Divisão de Gastroenterologia e Hepatologia Clínica do Instituto Central do HC-FMUSP tem desenvolvido atividades assistenciais eletivas especializadas em Hepatologia no Ambulatório de Especialidades Nível Secundário de São Paulo no Estado de São Paulo NGA-63 Várzea do Carmo. O objetivo do estudo é analisar o perfil farmacoterapêutico dos pacientes. Trata-se de um estudo transversal e retrospectivo, no qual pacientes foram atendidos pelo setor de Hepatologia e os dados encontrados foram submetidos à estatística descritiva. Os resultados demonstraram que 492 pacientes foram atendidos nesse ambulatório durante o período do estudo com a média de idade de 58,9 anos, frequência de $61,2 \%$ do sexo feminino e $74,8 \%$ residindo na capital paulista. Essa população foi atendida por outras diferentes especialidades médicas (cardiologia e endócrino, entre outras), e os principais diagnósticos hepáticos foram hepatite crônica B e C e esteatose hepática. Também foram identificadas comorbidades como diabetes, hipertensão arterial e dislipidemia. Boa parte da população tende a retirar a sua medicação nas Unidades Básicas de Saúde. Foi verificado que $30 \%$ dos pacientes fazem uso de mais de cinco medicamentos, sendo os mais prescritos o omeprazol $(208 ; 42,3 \%)$, metformina (132; $26,8 \%)$ e losartana $(80 ; 16,3 \%)$. Por se tratar de uma população adulta/idosa, com diversas comorbidades e com polimedicação, é importante estar atento ao uso racional do medicamento. $\mathrm{O}$ atendimento da equipe multiprofissional é importante para aplicar tomadas de condutas corretas para a segurança no uso de medicamentos e diminuir a oneração em gastos em saúde, melhorando a qualidade de vida do paciente.

Palavras-chave: hepatites, medicamento, polifarmácia, assistência ambulatorial, hepatologia, omeprazol.

\section{References}

1. Serra CG, Rodrigues PHA. Avaliação da referência e contrarreferência no Programa Saúde da Família na Região Metropolitana do Rio de Janeiro (RJ, Brasil). Ciênc Saúde Coletiva. 2010; 15(Supl 3):3579-86. 
2. Alves MLF, Guedes HM, Chianca TCM, Martins JCA. Rede de referência e contrarreferência para o atendimento de urgências em um município do interior de Minas Gerais- Brasil. Rev Med Minas Gerais. 2015; 25(4):469-75.

3. Bjerrum L, Søgaard J, Hallas J, Kragstrup J. Polypharmacy in general practice: differences between practitioners. Br J Gen Pract. 1999; 49(440):195-8.

4. Cotta LSF, Predebon SS, Didonet J, Mascarenhas M, Jacobus AP. Uso racional de omeprazol. Infarma. 2011; 23(9-12):32. Available from: http://revistas. cff.org.br/infarma/article/view/22.

5. Abbasinazari M, Panahi Y, Mortazavi SA, Fahimi F, Valizadegan G, Mohtashami $\mathrm{R}$, et al. Effect of a combination of omeprazole plus sustained release baclofen versus omeprazole alone on symptoms of patients with Gastroesophageal Reflux Disease (GERD). Iran J Pharm Res. 2014; 13(4):1221-6.

6. Yu M, Qian J, Guo D, Li L, Liu X. Severe adverse reactions caused by omeprazole: a case report. Exp Ther Med. 2016; 12(2):1103-6.

7. Oliveira JEP, Vencio S. Epidemiologia e prevenção do diabetes mellitus. Diretrizes da Sociedade Brasileira de Diabetes: 2014/2015. 2015:1-4. Available from: http://www.sgc.goias.gov.br/upload/arquivos/2014-05/diretrizessbd-2014.pdf.

8. Sociedade Brasileira de Cardiologia, Sociedade Brasileira de Hipertensão, Sociedade Brasileira de Nefrologia. V Diretrizes Brasileiras de Hipertensão Arterial. Arq Bras Cardiol. 2007; 89(3):e24-e79.

9. Armstrong MJ, Adams LA, Canbay A, Syn WK. Extrahepatic complications of nonalcoholic fatty liver disease. Hepatology. 2014; 59(3):1174-97.

10. Brunt EM. Nonalcoholic steatohepatitis. Semin Liver Dis. 2004; 24(1):3-20

11. Schwimmer JB, Celedon MA, Lavine JE, Salem R, Campbell N, Schork NJ, et al. Heritability of nonalcoholic fatty liver disease. Gastroenterology. 2009; 136(5):1585-92.

12. Chalasani N, Younossi Z, Lavine JE, Diehl AM, Brunt EM, Cusi K, et al.; American Gastroenterological Association; American Association for the Study of Liver Diseases; American College of Gastroenterologyh. The diagnosis and management of non-alcoholic fatty liver disease: practice guideline by the American Gastroenterological Association, American Association for the Study of Liver Diseases, and American College of Gastroenterology. Gastroenterology. 2012; 142(7):1592-609.

13. Bookman ID, Pham J, Guindi M, Heathcote EJ. Distinguishing nonalcoholic steatohepatitis from fatty liver: serum-free fatty acids, insulin resistance, and serum lipoproteins. Liver Int. 2006; 26(5):566-71.
14. D'Amico G, Tine F. Long-term low-dose maintenance pegylated interferon may prevent decompensation in cirrhotic patients with portal hypertension: are we there yet? Hepatology. 2012; 55(2):642-5.

15. Cirrose hepática: aspectos. Iida VH, Silva TJA, Silva ASF, Silva LFF, Alves VAF. Cirrose hepática: aspectos morfológicos relacionados às suas possíveis complicações. Um estudo centrado em necropsias. J Bras Patol Med Lab. 2005; 41(1):29-36. Available from: http://www.scielo.br/scielo.php?script=sci_ arttext\&pid=S1676-24442005000100008.

16. Xavier HT, Izar MC, Faria Neto JR, Assad MH, Rocha VZ, Sposito AC, et al. V Diretriz Brasileira de Dislipidemias e Prevenção da Aterosclerose. Arq Bras Cardiol. 2013; 101(4 supl 1):1-20.

17. Zipprich A, Seufferlein T, Dollinger MM. Subclinical ascites defines an intermediate stage between compensated and decompensated cirrhosis. Z Gastroenterol. 2012; 50(9):996-1001.

18. Hwang Y, Kim W, Kwon SY, Yu HM, Kim JH, Choe WH. Incidence of and risk factors for thyroid dysfunction during peginterferon $\alpha$ and ribavirin treatment in patients with chronic hepatitis C. Korean J Intern Med. 2015; 30(6):792-800.

19. Brouwer WP, Chan HL, Brunetto MR, Martinot-Peignoux M, Arends P, Cornberg M, et al.; Good Practice in using HBsAg in Chronic Hepatitis B Study Group (GPs-CHB Study Group). Repeated measurements of hepatitis B surface antigen identify carriers of inactive HBV during long-term followup. Clin Gastroenterol Hepatol. 2016; 14(10):1481-9.e5.

20. Invernizzi F, Viganò M, Grossi G, Lampertico P. The prognosis and management of inactive HBV carriers. Liver Int. 2016; 36(Suppl 1):100-4.

21. Brasil. Ministério da Saúde. Protocolo clínico e diretrizes terapêuticas para o tratamento da hepatite viral crônica C e coinfecções. Brasília; 2013. Available from: http://hepato.com/P_protocolos_consensos/protocolo_IP_2013 versao_2.pdf.

22. Brasil. Ministério da Saúde. Protocolo clínico e diretrizes terapêuticas para o tratamento da hepatite viral crônica C e coinfecções. Brasília; 2015. Available from: http://www.aids.gov.br/publicacao/2015/protocolo-clinico-e-diretrizes-terapeuticas-para-hepatite-c-e-coinfeccoes.

23. Jiménez-Pérez M, González-Grande R, España Contreras P, Pinazo Martínez I, de la Cruz Lombardo J, Olmedo Martín R. Treatment of chronic hepatitis $\mathrm{C}$ with direct-acting antivirals: The role of resistance. World J Gastroenterol. 2016; 22(29):6573-81. 